九州大学学術情報リポジトリ

Kyushu University Institutional Repository

\title{
Assessment of Nutrients Removal by Constructed Wet lands Using Reed Grass (Phragmites australis L.) and Vetiver Grass (Vetiveria Zizanioides L. )
}

KY, Nguyen Minh

Faculty of Environment and Natural Resources, Nong Lam University of Ho Chi Minh City HUNG, Nguyen Tri Quang

Faculty of Environment and Natural Resources, Nong Lam University of Ho Chi Minh City

MANH, Nguyen Cong

Faculty of Environment and Natural Resources, Nong Lam University of Ho Chi Minh City

LAP, Bui Quoc

Faculty of Chemistry and Environment, Thuy Loi University,

他

https://doi.org/10.5109/2558907

出版情報: 九州大学大学院農学研究院紀要. 65 (1)，pp.149-156，2020-02. Faculty of Agriculture， Kyushu University

バージョン :

権利関係 : 


\title{
Assessment of Nutrients Removal by Constructed Wetlands Using Reed Grass (Phragmites australis L.) and Vetiver Grass (Vetiveria Zizanioides L.)
}

\author{
Nguyen Minh KY', Nguyen Tri Quang HUNG ${ }^{1}$, Nguyen Cong MANH ${ }^{1}$, Bui Quoc LAP ${ }^{2 *}$, \\ Huyen Thi Thanh DANG ${ }^{3}$ and Akinori OZAKI ${ }^{4}$
}

Institute of Tropical Agriculture Kyushu University, Fukuoka 819-0395, Japan (Received October 31, 2019 and accepted November 14, 2019)

\begin{abstract}
Constructed wetland (CW) has been considered one of the low cost and effective wastewater treatment technologies for application in Vietnam. This paper attempted to evaluate the nutrient absorption ability of reed grass (Phragmites australis L.) and vetiver grass (Vetiveria Zizanioides L.) utilized in the vertical flow constructed wetland systems. Different hydraulic loading rates of $500 \mathrm{ml} / \mathrm{min} / \mathrm{m}^{2}, 1000 \mathrm{ml} / \mathrm{min} /$ $\mathrm{m}^{2}$ and $1500 \mathrm{ml} / \mathrm{min} / \mathrm{m}^{2}$ were tried. The results showed that the nutrient removal percentage was highest at the hydraulic loading rate of $500 \mathrm{ml} / \mathrm{min} / \mathrm{m}^{2}$. There was no statistically significant difference in nutrient removal between reed grass and vetiver at the same loading rate $(p>0.05)$. Nevertheless, at the same loading level, the nutrient removal of the wetlands with plants was always higher than those without the plants $(p<0.05)$. The effluent from the vertical constructed wetlands using plants all met the National technical regulation of surface water quality for agricultural irrigation purposes (column B1 in QCVN 08-MT: 2015/ BTNMT). Thus, the constructed wetland using reed grass and vetiver grass would be quite a promising low cost technology for treatment of wastewater for irrigation purpose.
\end{abstract}

Key words: Hydraulic loading rate, Nutrients removal, Phragmites australis L., Vertical flow constructed wetland, Vetiveria zizanioides L.

\section{INTRODUCTION}

Vietnam has been now facing with an increasing utilization of untreated wastewater for agricultural irrigation. This has led to increasing number of poisonous food cases and affecting the human health to a severe level. People now prefer growing their vegetables for themselves to buying from the farmers who irrigate their plants with dirty water. It is the limited capacity (budget and human resources) of the local government and high construction and operation costs of a wastewater treatment plant that leaves more than $90 \%$ of wastewater from rural areas untreated.

Due to the urbanization and industrialization, a significant amount of the industrial and domestic wastewater was discharged to the environment that threatens surrounding aquatic systems such as canals and irrigation canals in Vietnam. The surface water quality including water quality for irrigation was vulnerable due to the industrial and agricultural activities (Carpenter et al., 1998; Jarvie et al., 1998). Pollution of nutrients affected badly the ecosystems, causing eutrophication in water bodies (Guy et al., 2012; Manuel, 2014; Xinyu et al., 2017). On the other hand, the capacity of irrigation canals is limited, while more and more water is needed for aquaculture activities. Regarding to water in the irrigation systems, it requires the suitable quality standards

Faculty of Environment and Natural Resources, Nong Lam University of Ho Chi Minh City, VIETNAM

${ }^{2 *}$ Faculty of Chemistry and Environment, Thuyloi University, 175 Tay Son Street, Dong Da District, Hanoi, VIETNAM. Corresponding author (Email: buiquoclap@tlu.edu.vn)

${ }^{3}$ Faculty of Environmental Engineering, National University of Civil Engineering, Vietnam

Institute of Tropical Agriculture Kyushu University, JAPAN
(Maimon et al., 2010, Travis et al., 2010). In this situation, the question is whether to find the technologies that have the appropriate cost to treat the contaminated waters for agricultural cultivation.

Constructed wetland (CW) technology has been well known as an effective wastewater treatment technology solution (ElZein et al., 2016) with advantages such as low cost of construction and low cost for operation and maintenance (Kadlec and Wallace, 2009). It has been shown to be capable of treating municipal, domestic, industrial, sewage, aquaculture wastewaters, etc. (Dallas et al., 2004; Vymazal, 2009; Katarzyna and Magdalena, 2017). In particular, there have been many applied studies to examine the possibility of reusing the wastewaters for the agricultural irrigation purpose (Farid et al., 2014; Zeshan et al., 2018).

According to Kadlec and Knight (1996), the main kinds of CWs are free water subsurface (FWS) CWs and subsurface flow (SSF) CWs, in which, SSF CWs are further classified into vertical subsurface flow (VSSF) and horizontal subsurface flow (HSSF) systems. The removal efficiencies of FWS CWs were unstable and not so high $(<50 \%)$ compared to subsurface systems for total suspended solid (TSS), chemical oxygen demand (COD), biochemical oxygen demand (BOD), total phosphorous (TP) and total nitrogen (TN) (Zhang et al., 2014). Many previous studies revealed that the performance of constructed wetlands varied with different plant species and their productivities (Zhang et al., 2014). The total nitrogen (TN) and total phosphorous (TP) removal rates were $58.6 \%$ and $66.5 \%$ for Typha angustifolia; $45 \%$ and $81.7 \%$ for Thaliade albata; $52.8 \%$ and $40 \%$ for Anthurium andreanum, respectively; while they were $15 \%$ and $52 \%$ for Canna indica; $23.97 \%$ and $30.69 \%$ for Lemna minor; $25.57 \%$ and 
46.45\% for Azolla pinnata (Muvea et al., 2019). In particular, vetiver grass was studied and applied to treat different types of polluted water by previous researchers (Roongtanakiat and Chairoj, 2001; Lu et al., 2004; Dudai et al., 2006; Truong et al., 2010; Datta et al., 2013; Seroja et al., 2018). Similarly, the reed grass (Phragmites australis L.) was also used as an effective target for the treatment of water pollution and environmental protection (Havens et al., 2003; Abou-Elela et al., 2012; Mirco and Attilio, 2013; Aboubacar et al., 2018).

Therefore, this paper aims at evaluating the application of environmental friendly and low cost technology such as the vertical subsurface (VSS) constructed wetland (CW) for the treatment of wastewater for irrigation. Two kinds of floras, reed grass (Phragmites australis L.) and vetiver grass (Vetiveria Zizanioides L.), were employed. The impact of hydraulic loading rates was also considered in this study.

\section{MATERIALS AND METHODS}

\section{Feed wastewater}

The input for this experiment was the contaminated water from the canal D in Thuan An Town, Binh Duong Province as shown in Figure 1. Thuan An town, with a total natural area of $82.46 \mathrm{~km}^{2}$ and a population of 361,640 people, belongs to the dynamic economic zone in the South of Vietnam.

The canal D receives significant domestic and industrial wastewater from Areco residential area and Dong An Industrial Zone. Water quality of canal D has been heavily polluted by nutrients and organic matters. Monitoring data showed that this water did not meet the quality standard for agricultural irrigation according to Vietnam's national technical regulation for surface water quality (QCVN 08-MT: 2015/BTNMT). Characteristics of the contaminated water used in the experiment, with different loading rates of $500 \mathrm{ml} / \mathrm{min} / \mathrm{m}^{2}$ (T1), $1000 \mathrm{ml} /$ $\mathrm{min} / \mathrm{m}^{2}$ (T2) and $1500 \mathrm{ml} / \mathrm{min} / \mathrm{m}^{2}$ (T3), are shown in Table 1. It can be seen from Table 1 that amonium nitrogen $\left(\mathrm{NH}_{4}-\mathrm{N}\right)$ was higher than the standard value most of the time, while phosphate $\left(\mathrm{PO}_{4}^{3-}\right)$ was occasionally beyond the standard.

\section{Plants used for constructed wetland}

Based on the results of previous studies, local availability and relatively high treatment efficiency, Phragmites australis and Vetiverria zizanioides $L$ were selected for the study (Havens et al., 2003; Danh et al., 2009; Indrayatie et al., 2013; Abou-Elela and Hellal, 2012; Mirco and Attilio, 2013; Effendi et al., 2015;


Fig. 1. Location of experimental set up.

Table 1. Characteristics of pre-treated water quality

\begin{tabular}{|c|c|c|c|c|c|c|}
\hline \multirow{2}{*}{ Load $^{b}$} & \multicolumn{6}{|c|}{ Parameters, (mg/l) } \\
\hline & $\mathrm{TP}$ & $\mathrm{PO}_{4}{ }^{3-}$ & TKN & $\mathrm{N}-\mathrm{NH}_{4}$ & $\mathrm{~N}-\mathrm{NO}_{2}$ & $\mathrm{~N}-\mathrm{NO}_{3}$ \\
\hline $\mathrm{T} 1$ & $1.13 \pm 0.4$ & $0.06 \pm 0.02$ & $50.39 \pm 12.2$ & $29.77 \pm 2.7$ & $0.01 \pm 0.01$ & $0.08 \pm 0.03$ \\
\hline $\mathrm{T} 2$ & $2.38 \pm 0.06$ & $1.41 \pm 0.09$ & $33.39 \pm 6.19$ & $17.01 \pm 6.14$ & $0.02 \pm 0.01$ & $0.06 \pm 0.04$ \\
\hline T3 & $1.54 \pm 0.8$ & $0.19 \pm 0.1$ & $27.79 \pm 0.38$ & $18.16 \pm 0.5$ & $0.05 \pm 0.04$ & $0.10 \pm 0.05$ \\
\hline QCVN 08-MT: 2015 (B1) & N/A & 0.3 & N/A & 0.9 & 0.05 & 10 \\
\hline
\end{tabular}

${ }^{a}$ Average value \pm Standard deviation; QCVN 08-MT: 2015/BTNMT: National technical regulation on surface water quality; Column B1 - For irrigation purpose.

${ }^{b}$ Hydraulic loading rates: $500 \mathrm{ml} / \mathrm{min} / \mathrm{m}^{2}$ (T1), $1000 \mathrm{ml} / \mathrm{min} / \mathrm{m}^{2}$ (T2) and $1500 \mathrm{ml} / \mathrm{min} / \mathrm{m}^{2}$ (T3) 




Phragmites australis



Vetiverria zizanioides

Fig. 2. Flora used in the experiement.

Badejo et al., 2018; Aboubacar et al., 2018). These grasses were quite common in the Aquatic Biological Collection Garden of Nong Lam University of Ho Chi Minh City. The relatively mature grasses with strong stems ( 0.5 to $1 \mathrm{~cm}$-wide and 40 to $50 \mathrm{~cm}$ long) were selected. After that, their leaves were divided into bundles of 4 to 5 stems. Those seeding bundles were planted every $20 \mathrm{~cm}$ in distance, with density of 20 plants $/ \mathrm{m} 2$ in the constructed wetland systems. The experiment was conducted after they have been planted for 5 months with a growing height of 0.6 to $0.8 \mathrm{~m}$.

\section{Experimental design}

The experiment was designed following the factorial experiment approach. Two factors were examined including hydraulic loading rates and the type of plants. In which, the loading rates included 3 levels of $500 \mathrm{ml}$ $\mathrm{min} / \mathrm{m}^{2}$ (T1), $1000 \mathrm{ml} / \mathrm{min} / \mathrm{m}^{2}$ (T2) and $1500 \mathrm{ml} / \mathrm{min} / \mathrm{m}^{2}$ (T3). In specific, these 3 loading levels (T1, T2, T3) were tested through the VSS constructed wetlands with Reed Grass $\left(\mathrm{S}_{\mathrm{T} 1}, \mathrm{~S}_{\mathrm{T} 2}, \mathrm{~S}_{\mathrm{T} 3}\right)$, Vetiver Grass $\left(\mathrm{V}_{\mathrm{T} 1}, \mathrm{~V}_{\mathrm{T} 2}, \mathrm{~V}_{\mathrm{T} 3}\right)$ and without the plants for the reference $\left(\mathrm{C}_{\mathrm{T} 1}, \mathrm{C}_{\mathrm{T} 2}, \mathrm{C}_{\mathrm{T} 3}\right)$. Number of experiments were determined via the randomized complete block design method, a standard design for agricultural experiments in which similar experimental units are grouped into blocks or replicates. Triplicates were conducted in this study (Table 2).

Regarding the layout of the experimental set up, the wastewater from the canal D was pumped into a feed tank, which was placed $1.5 \mathrm{~m}$ higher than the surface of the VSS constructed wetland systems. The wastewater was pumped from the tank into the VSS CW systems by quantitative pumps (\#72-370-000, MANOSTAT, USA) to

Table 2. Experimental design

\begin{tabular}{cccc}
\hline Load & Reed grass $(\mathrm{S})$ & Vetiver $(\mathrm{V})$ & Reference $(\mathrm{C})$ \\
\hline $\mathrm{T} 1$ & $\mathrm{~S}_{\mathrm{T} 1}$ & $\mathrm{~V}_{\mathrm{T} 1}$ & $\mathrm{C}_{\mathrm{T} 1}$ \\
$\mathrm{~T} 2$ & $\mathrm{~S}_{\mathrm{T} 2}$ & $\mathrm{~V}_{\mathrm{T} 2}$ & $\mathrm{C}_{\mathrm{T} 2}$ \\
$\mathrm{~T} 3$ & $\mathrm{~S}_{\mathrm{T} 3}$ & $\mathrm{~V}_{\mathrm{T} 3}$ & $\mathrm{C}_{\mathrm{T} 3}$ \\
\hline
\end{tabular}

control the loading rate and retention time corresponding to the each experiment (Fig. 3).

Each VSS CW system had a volume of $1000 \mathrm{~L}(1 \mathrm{~m} \times$ $1 \mathrm{~m} \times 1 \mathrm{~m})$. Fig. 4 depicts clearly its structure, including

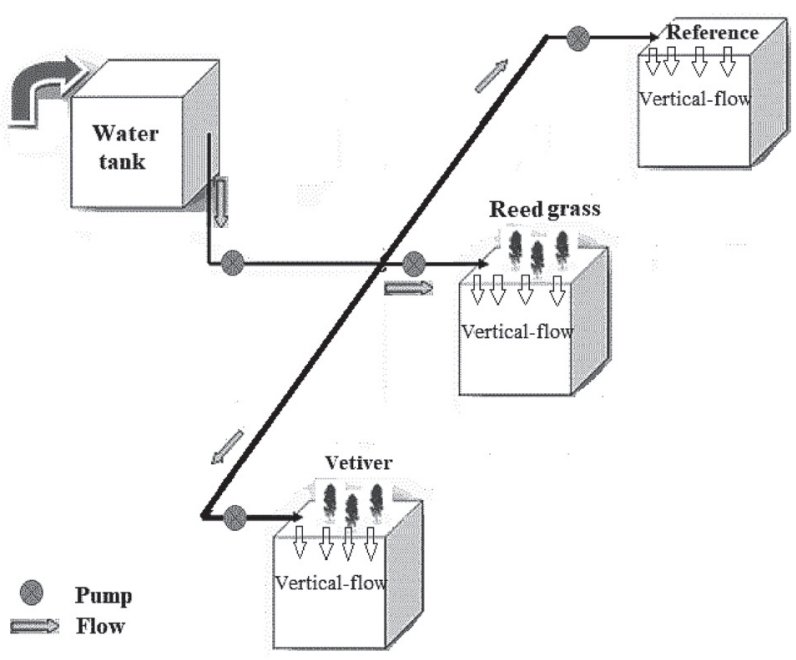

Fig. 3. Diagram of experiment set up.

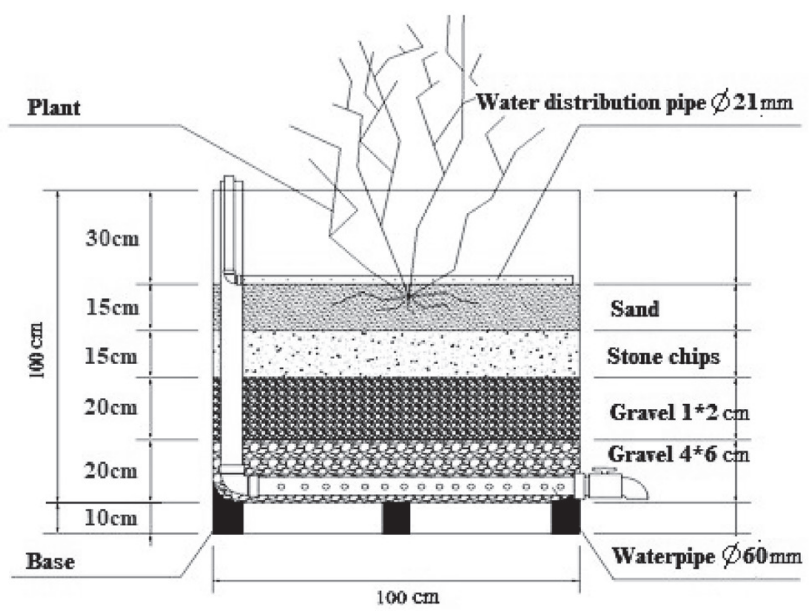

Fig. 4. Cross - section of Vertical subsurface flow constructed wetland system. 
a layer of gravel (size $4 \mathrm{~cm} \times 6 \mathrm{~cm}$ ) with $20 \mathrm{~cm}$ thick, second layer of gravel (size $1 \mathrm{~cm} \times 2 \mathrm{~cm}$ ) with $20 \mathrm{~cm}$ thick, a layer of stone chips with $15 \mathrm{~cm}$ thick, and top sand grains $(\phi=1 \div 2 \mathrm{~mm})$ with $15 \mathrm{~cm}$ thick. The porosity of the whole filter media was $40 \%$. The plants were grown from the top sand. Feed wastewater was provided via a perforated pipe $(\phi=21 \mathrm{~mm})$ from the top, then it was filtered through medial vertically and collected at the bottom by a water pipe $(\phi=60 \mathrm{~mm})$. For the reference system, there was no plants on top.

\section{Statistical and analytical methods}

The water samples were collected from the inlet and outlet of the VSS CW systems, once per week, for 10 weeks. The samples were analyzed at the Laboratory of Environment Engineering, Center for Environmental Technology and Natural Resource Management, Nong Lam University of Ho Chi Minh City to determine TP, $\mathrm{PO}_{4}^{3-}, \mathrm{TKN}, \mathrm{NH}_{4}{ }^{+}-\mathrm{N}, \mathrm{NO}_{2}-\mathrm{N}$ and $\mathrm{NO}_{3}-\mathrm{N}$. The analysis of these parameters was complied with the "Standard Methods for the Examination of Water and Wastewater" (APHA, 2012).

The removal efficiencies ( $\mathrm{H} \%$ ) of treatment system (reed grass, vetiver and control) were calculated based on the following formula:

$$
\mathrm{H} \%=\left\{\left(\mathrm{C}_{\text {inf }}-\mathrm{C}_{\text {eff }}\right) / \mathrm{C}_{\text {inf }}\right\} * 100
$$

In which, $\mathrm{C}_{\text {inf }}$ is initial concentration and $\mathrm{C}_{\text {eff }}$ is final concentration of corresponding parameter.

ANOVA analysis was employed to find significantly statistical differences between experiments. All statistical analyses were performed using SPSS 13.0 with significance was $\mathrm{p}<0.05$.

\section{RESULTS AND DISCUSSION}

\section{Treatment efficiency of VSS CW systems at load- ing level of $500 \mathrm{ml} / \mathrm{min} / \mathrm{m}^{2}$ (T1)}

Fig. 5 shows the pre- and post-treatment concentrations of total phosphorus (TP) and $\mathrm{PO}_{4}^{3-}$ in $\mathrm{T} 1$ experiment. The concentrations of $\mathrm{TP}$ and $\mathrm{PO}_{4}{ }^{3-}$ before treatment were respectively $1.13 \pm 0.39$ and $0.06 \pm 0.02 \mathrm{mg} / \mathrm{l}$. After treatment, there was a clearly decrease in concentrations with floras $(\mathrm{V} 1, \mathrm{~S} 1)$ and without floras (reference $\mathrm{C} 1)$. The treatment efficacies of $\mathrm{TP}$ and $\mathrm{PO}_{4}{ }^{3-}$ in



Fig. 5. Phosphous removal efficiency at $500 \mathrm{ml} / \mathrm{min} / \mathrm{m}^{2}$ hydraulic loading rate. the reference CW model were $93.4 \pm 1.8$ and $61.6 \pm$ $29.2 \%$, in the CW model using reed grass were $95.4 \pm 1.5$ and $54.4 \pm 8.5 \%$; and in the $\mathrm{CW}$ model using vetiver grass were $95.0 \pm 0.7$ and $50.1 \pm 11.5 \%$, respectively (Fig. 5). The effluent eventually met the national technical regulation on surface water quality, used for agricultural irrigation purposes (QCVN 08-MT: 2015/ BTNMT, Column B1). Overall, the TP removal efficiency was quite high $(>90 \%)$.

Despite the removal of phosphorous was substantial, it was not that significant for nitrogen (TKN, $\mathrm{NH}_{4}-\mathrm{N}$ ) (Fig. 6). Contrary to the decline of TKN and $\mathrm{NH}_{4}-\mathrm{N}$ concentrations, the concentrations of $\left(\mathrm{NO}_{2}-\mathrm{N}+\mathrm{NO}_{3}-\mathrm{N}\right)$ increased more than 100 times in both the control and the ones with floras. This proved that nitrogen has well transferred from $\mathrm{NH}_{4}-\mathrm{N}$ form to nitrite $\mathrm{NO}_{2}$ and nitrate $\mathrm{NO}_{3}$ forms during the oxidation process within the system. Accordingly, the reduction of TKN or TN was observed and the $\mathrm{NH}_{4}-\mathrm{N}$ concentration was lower than the standard eventually. The efficiency of TKN treatment by reed grass was $74 \pm 17 \%$ and $68 \pm 21 \%$ for $\mathrm{NH}_{4}-\mathrm{N}$; the similar was observed for vetiver grass of $68 \pm$ $16 \%$ and $64 \pm 15 \%$, respectively. Meanwhile, the corresponding values in the reference $\mathrm{CW}$ model were $60 \pm$ $13 \%$ and $52 \pm 10 \%$. There seems to be a difference in nitrogen removal between the control and the ones with plants.

These treatment results were somewhat comparable with other studies on nutrient removal using vertical flow constructed wetlands (Vymazal et al., 2002; Brix and Arias, 2005; Vymazal et al., 2009; Zurita et al., 2009). For instance, Brix and Arias (2005) found that the $\mathrm{NH}_{4}-\mathrm{N}$ treatment efficiency was $78 \%$, TKN was $43 \%$ and TP was $25 \%$ when using vertical flow wetland system for domestic wastewater treatment in Denmark. This high conversion efficiency was due to the characteristics of vertical subsurface flow within the wetland (Kadlec and Wallace, 2009).

\section{Treatment efficiency of vertical flow model with loading level of $1000 \mathrm{ml} / \mathrm{min} / \mathrm{m}^{2}$ (T2)}

Removal results of total phosphorus (TP) and $\mathrm{PO}_{4}^{3-}$ are shown in Fig. 7 for the experiment T2. The concentrations of TP and $\mathrm{PO}_{4}^{3-}$ before treatment were $2.38 \pm$ 0.06 and $1.41 \pm 0.09 \mathrm{mg} / \mathrm{l}$, respectively. Again, a

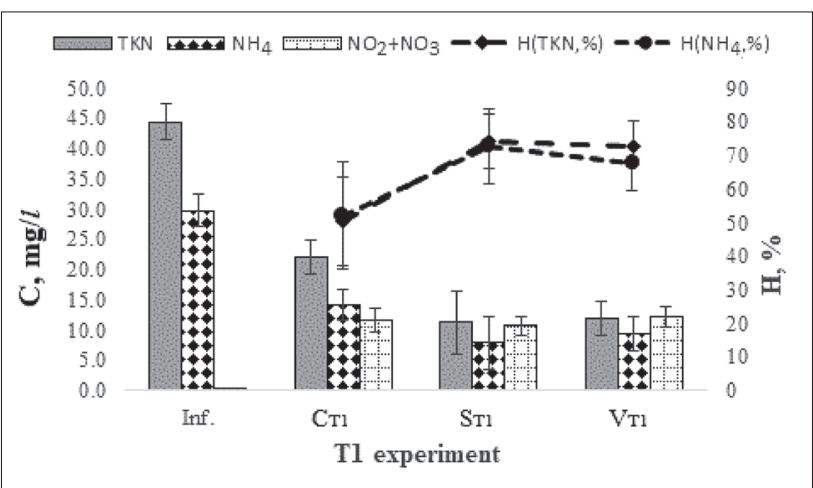

Fig. 6. Nitrogen removal efficiency at $500 \mathrm{~m} / / \mathrm{min} / \mathrm{m}^{2}$ hydraulic loading rate. 
decrease in concentrations of these two parameters in both reference and ones with plants. However, the treatment efficiencies of $\mathrm{TP}$ and $\mathrm{PO}_{4}^{3-}$ in this case were quite low, i.e., $12.93 \pm 12.5 \%$ and $19.65 \pm 12.68 \%$ for the reference system, $23.91 \pm 3.17$ and $26.05 \pm 6.25 \%$ for the system using the reed grass; and were $25.91 \pm 3.67$ and $23.69 \pm 5.98 \%$ for the system with the vetiver grass, respectively (Fig. 7).

The same low removal efficiencies were observed for $\mathrm{TKN}, \mathrm{NH}_{4}-\mathrm{N}$ and $\left(\mathrm{NO}_{2}-\mathrm{N}+\mathrm{NO}_{3}-\mathrm{N}\right)$ at $\mathrm{T} 2$ loading rate (Fig. 8). The reed grass seemed not to work well at this load or the hydraulic loading rate affected the absorption of nutrient of reed grass to some certain extent, leading to lower treatment competence than the control system (without grass). The system with vetiver grass still performed better than the control at $1000 \mathrm{ml} / \mathrm{min} / \mathrm{m}^{2}$, but not as well as that at $500 \mathrm{ml} / \mathrm{min} / \mathrm{m}^{2}$ (34\% versus $69 \%$ for $\mathrm{NH}_{4}-\mathrm{N}$ parameter). It should be noted that there was not much nitrification process happening within the systems. That was why the $\mathrm{NH}_{4}-\mathrm{N}$ and TKN removal efficiencies were rather modest. Previous study indicated a conversion efficiency of $60 \%$ for nitrate using VSS CW at the similar loading rate (Prochaska et al., 2007), which was a bit higher than that in this study.

\section{Treatment efficiency of vertical flow model with loading level of $1500 \mathrm{ml} / \mathrm{min} / \mathrm{m}^{2}$ (T3)}

At this loading rate, the initial concentrations of TP and $\mathrm{PO}_{4}^{3-}$ were quite low of $1.54 \pm 0.8$ and $0.19 \pm 0.07$

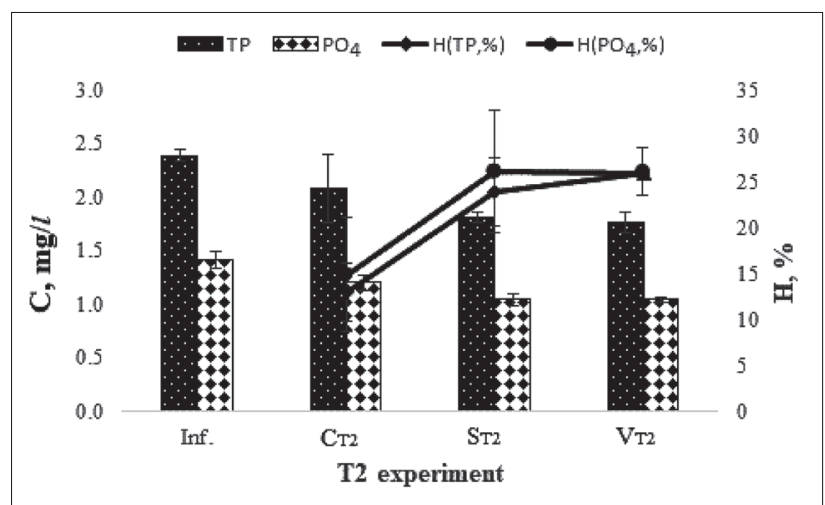

Fig. 7. Phosphous removal efficiency at $1000 \mathrm{ml} / \mathrm{min} / \mathrm{m}^{2}$ hydraulic loading rate.

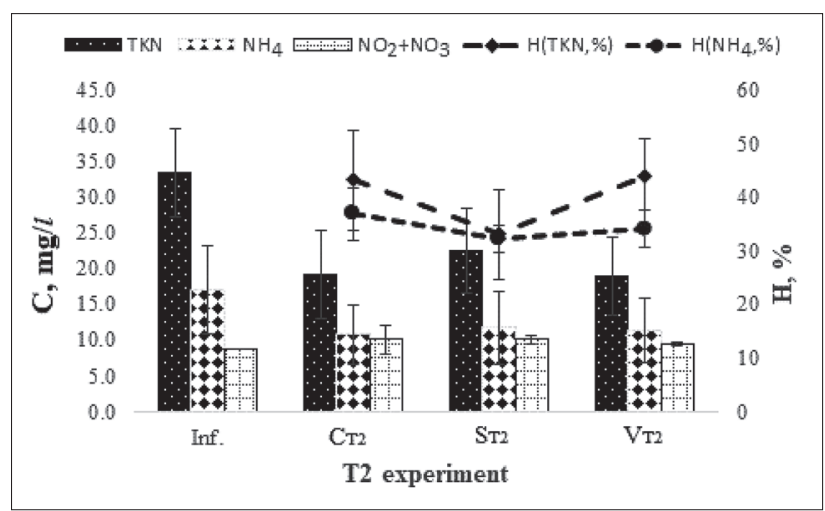

Fig. 8. Nitrogen removal efficiency at $1000 \mathrm{ml} / \mathrm{min} / \mathrm{m}^{2}$ hydraulic loading rate. $\mathrm{mg} / l$, respectively (lower than the permit value).

Still after the VSS CW systems, a decrease in $\mathrm{PO}_{4}^{3-}$ concentration was seen in all testing systems (Fig. 9). The TP removals of reed and vetiver grass varied from 20-30\%, which was similar to the previous loading rates. In the reference model, the treatment efficiency of TP was $5.5 \pm 7.3 \%$ and of $\mathrm{PO}_{4}^{3-}$ was $74.8 \pm 5.6 \%$. Meanwhile, the treatment efficiency in the CW model using reed grass was $19.5 \pm 7.3 \%$ for $\mathrm{TP}$ and $60.5 \pm$ $24.4 \%$ for $\mathrm{PO}_{4}^{3-}$, similarly, the treatment efficiency in the CW model using vetiver grass for TP and $\mathrm{PO}_{4}^{3-}$ were 28.7 $\pm 4.8 \%$ and $73.6 \pm 10.6 \%$, respectively.

Fig. 10 showed that the efficiency of TKN treatment in reed grass model was $62.9 \pm 1.8 \%$ and $59.4 \pm 0.5 \%$ for $\mathrm{NH}_{4}-\mathrm{N}$, in vetiver grass model was $61.1 \pm 10.6 \%$ for $\mathrm{TKN}$ and $55.2 \pm 12.3 \%$ for $\mathrm{NH}_{4}-\mathrm{N}$. Meanwhile, the corresponding values in the reference model were $48.1 \pm$ $2.7 \%$ and $41.4 \pm 4.5 \%$. Thus, a large variation in the efficiency of TKN and $\mathrm{NH}_{4}-\mathrm{N}$ treatment in both reference and experimental models was recorded (Fig. 10). The nitrogen treatment at this loading rate followed similar trend with that at $500 \mathrm{ml} / \mathrm{min} / \mathrm{m}^{2}$, only at slightly different magnitude. The $\mathrm{TN}$ and $\mathrm{NH}_{4}-\mathrm{N}$ removal rates of both systems with floras were about $60 \%$, which was $25 \%$ higher than those of the reference one.

\section{Discussions}

The treatment of nitrogen and phosphorous in the CW model was reported to relate to the plant uptake in

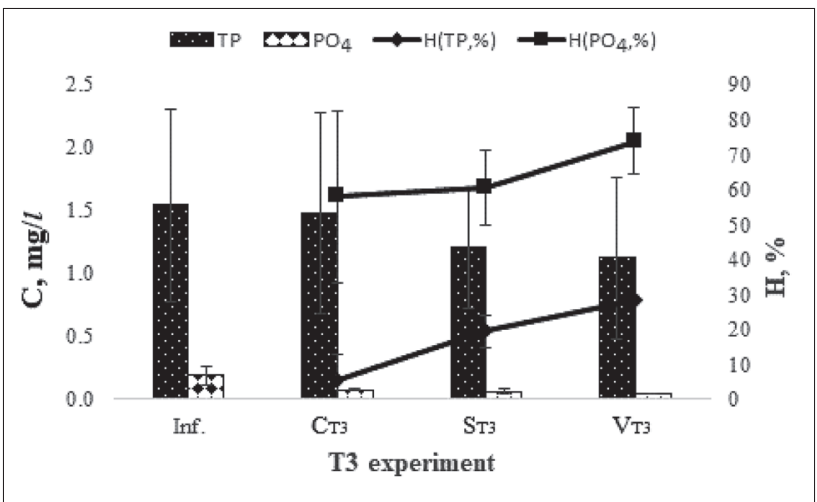

Fig. 9. Phosphous removal efficiency at $1500 \mathrm{ml} / \mathrm{min} / \mathrm{m}^{2}$ hydraulic loading rate.

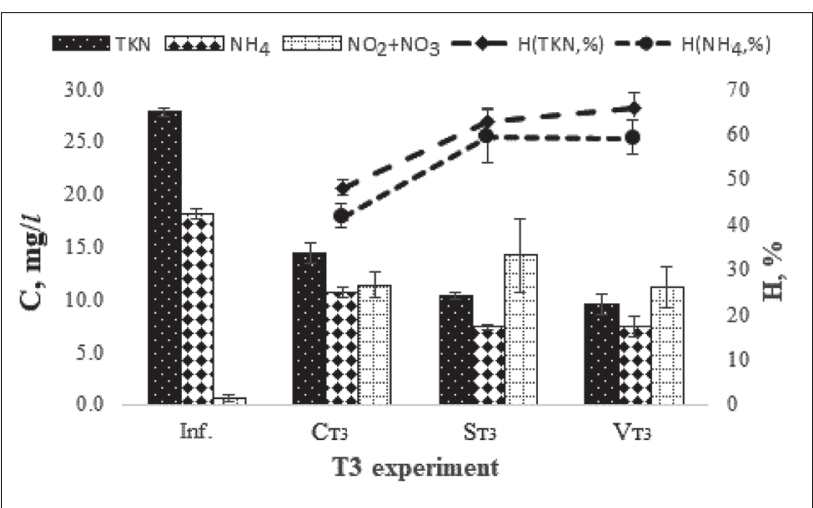

Fig. 10. Nitrogen removal efficiency at $1500 \mathrm{ml} / \mathrm{min} / \mathrm{m}^{2}$ hydraulic loading rate. 
the system (He and Mankin, 2002; Kadlec and Wallace, 2009). In fact, the presence of plants has increased the biofilms formed around the roots, which play important roles in the oxidation, adsorption or update of the nutrients. The nitrogen transfer was observed better in the constructed wetlands with higher biomass growth rate (Tran et al., 2019). According to Vymazal (2010), the CWs were artificial systems designed and used by natural processes under the influence of plants and soil; and they were, in fact, a collection of interactions of microorganisms involved in wastewater treatment. The microorganisms that live in the filter material and stick to the root system of the plant decompose the pollutants for their living activities and the plants also absorb another part. In the study of the role of plants, many researchers found that the number of nitrogen-treated microorganisms in plant-grown treatments was always higher than the reference without plants; thus leading to higher nitrogen treatment efficiency (Lee and Scholz, 2007; Kantawanickul et al., 2009). Wang et al. (2011) also revealed that the phosphorus decomposition activity of microorganisms in tree-grown experiments was higher than the reference without plants. It should be noted that besides adsorption and plant uptake, the phosphorous could be treated via precipitation (Du et al., 2017).

Table 3. ANOVA result of TP removal efficiency (\%) for different loading rates (T1, T2 and $\mathrm{T} 3$ )

\begin{tabular}{cccccc}
\hline Load & Tank & $\mathrm{N}$ & Mean & Min & Max \\
\hline $\mathrm{T} 1$ & $\mathrm{C}_{\mathrm{T} 1}$ & 3 & $93.4 \pm 1.8^{\mathrm{d}}$ & 92.3 & 95.5 \\
& $\mathrm{~S}_{\mathrm{T} 1}$ & 3 & $95.4 \pm 1.5^{\mathrm{d}}$ & 93.7 & 96.4 \\
& $\mathrm{~V}_{\mathrm{T} 1}$ & 3 & $95.0 \pm 0.7^{\mathrm{d}}$ & 94.6 & 95.8 \\
$\mathrm{~T} 2$ & $\mathrm{C}_{\mathrm{T} 2}$ & 3 & $12.9 \pm 12.5^{\mathrm{ab}}$ & 1.6 & 26.4 \\
& $\mathrm{~S}_{\mathrm{T} 2}$ & 3 & $23.9 \pm 3.2^{\mathrm{b}}$ & 22.0 & 27.6 \\
& $\mathrm{~V}_{\text {T2 }}$ & 3 & $25.9 \pm 3.7^{\mathrm{b}}$ & 23.5 & 30.1 \\
$\mathrm{~T} 3$ & $\mathrm{C}_{\mathrm{T} 3}$ & 3 & $5.5 \pm 7.4^{\mathrm{a}}$ & 0.9 & 14.0 \\
& $\mathrm{~S}_{\text {T3 }}$ & 3 & $19.5 \pm 7.3^{\mathrm{bc}}$ & 13.3 & 27.6 \\
& $\mathrm{~V}_{\text {T3 }}$ & 3 & $28.7 \pm 4.7^{\mathrm{b}}$ & 23.5 & 32.7
\end{tabular}

Note: ${ }^{a, b, c, d}$ : Means with no common letters differ significantly $(p<0.05)$
It was found in the study that the nutrient removal rate of the CWs system with Canna generalis tended to decrease gradually when increasing the hydraulic loading rates (Tran et al., 2019). Similar trend was obtained in this study, when the loading rates increased, phosphorous removal decreased from about $50 \%$ to $25 \%$, but the nitrogen $\left(\mathrm{NH}_{4}-\mathrm{N}\right)$ did not really follow that trend. It is worth noting that the TP treatment efficiency was better with plants than without plants.

The results of ANOVA showed that the factors of plant types and loading rates both had a significant impact on TP treatment efficiency (Table 3). However, these two factors did not interact with the TP treatment efficiency $(p>0.05)$.

For nitrogen removal (TKN and $\mathrm{NH}_{4}-\mathrm{N}$ ), according to ANOVA statistics, there was a significant impact of plant types on both $\mathrm{TKN}$ and $\mathrm{NH}_{4}-\mathrm{N}$ treatment efficiency $(p<0.05)$. On the other hand, the loading rates also had a substantial influence on the efficiency of TKN treatment (Table 4).

In addition, it was found that there was no statistically significant difference on nitrogen and phosphor treatment efficiency between the reed grass and vetiver grass at the same loading rate $(p>0.05)$. The possible explanation may be due to the mature of the plants. In this study, the tests were conducted after the floras were planted for 5 months (from the date of seeding into the CW testing systems). At this age, they might be not mature enough to establish a strong root system and make a difference in absorption capacities by the two species (reed and vetiver). Wang et al. (2011) determined that the impact of accelerating nutrient uptake by plants in the fast growing stage was unknown and root microbial community usually was more active at the stage of being mature. Another possible explanation for the difference in phosphorous and nitrogen removal was that more nitrogen-favored microorganisms were available in the biofilms. Nevertheless, the removal of both phosphorous and nitrogen could be enhanced by adding a waste stabilization pond (WSP) after the constructed wetland (Tran et al., 2019).

Table 4. ANOVA results of $\mathrm{TKN}$ and $\mathrm{NH}_{4}-\mathrm{N}$ removal efficiency (\%) for different loading rates (T1, $\mathrm{T} 2$ and $\mathrm{T} 3$ )

\begin{tabular}{lllllllll}
\hline \multicolumn{7}{c}{ TKN } \\
\hline Load & Tank & $\mathrm{N}$ & Mean & Min & Max & Mean & Min & Max \\
$\mathrm{T} 1$ & $\mathrm{C}_{\mathrm{T} 1}$ & 3 & $50.44 \pm 3.37^{\text {bc }}$ & 46.63 & 53.04 & $52.01 \pm 9.83^{\text {bc }}$ & 43.35 & 62.70 \\
& $\mathrm{~S}_{\mathrm{T} 1}$ & 3 & $74.23 \pm 13.12^{\mathrm{d}}$ & 62.94 & 88.63 & $72.78 \pm 15.96^{\mathrm{d}}$ & 62.77 & 91.20 \\
& $\mathrm{~V}_{\mathrm{T} 1}$ & 3 & $72.73 \pm 8.20^{\mathrm{d}}$ & 63.99 & 80.26 & $67.68 \pm 11.15^{\mathrm{d}}$ & 60.61 & 80.55 \\
$\mathrm{~T} 2$ & $\mathrm{C}_{\mathrm{T} 2}$ & 3 & $43.21 \pm 7.61^{\mathrm{ab}}$ & 34.42 & 47.72 & $36.89 \pm 5.20^{\mathrm{a}}$ & 32.62 & 42.69 \\
& $\mathrm{~S}_{\mathrm{T} 2}$ & 3 & $33.10 \pm 9.35^{\mathrm{a}}$ & 24.74 & 43.21 & $32.17 \pm 4.97^{\mathrm{a}}$ & 26.58 & 36.10 \\
& $\mathrm{~V}_{\mathrm{T} 2}$ & 3 & $43.92 \pm 8.36^{\mathrm{ab}}$ & 37.54 & 53.39 & $34.08 \pm 2.63^{\mathrm{a}}$ & 31.06 & 35.82 \\
$\mathrm{~T} 3$ & $\mathrm{C}_{\mathrm{T} 3}$ & 3 & $48.10 \pm 2.68^{\mathrm{c}}$ & 45.14 & 50.38 & $41.43 \pm 4.46^{\text {ab }}$ & 38.36 & 46.56 \\
& $\mathrm{~S}_{\mathrm{T} 3}$ & 3 & $62.92 \pm 1.78^{\text {cd }}$ & 61.88 & 64.98 & $59.37 \pm 0.54^{\text {cd }}$ & 58.99 & 60.00 \\
& $\mathrm{~V}_{\text {T3 }}$ & 3 & $65.81 \pm 2.85^{\mathrm{d}}$ & 63.18 & 68.84 & $58.95 \pm 5.85^{\text {cd }}$ & 52.21 & 62.77 \\
\hline
\end{tabular}

Note: ${ }^{a, b, c, d}$ : Means with no common letters differ significantly $(p<0.05)$. 


\section{CONCLUSIONS}

This study has investigated and evaluated the ability to absorb nutrients $(\mathrm{N}, \mathrm{P})$ in contaminated surface water sources. The experiment was designed using randomized complete block design method with two factors, i.e., types of floras (reed grass and vetiver) and hydraulic loading rates. (500 $\mathrm{ml} / \mathrm{min} / \mathrm{m}^{2}$ (T1), $1000 \mathrm{ml} / \mathrm{min} / \mathrm{m}^{2}$ (T2) and $1500 \mathrm{ml} / \mathrm{min} / \mathrm{m}^{2}$ (T3)). It was found that the treatment efficacy of both phosphorous and nitrogen was the highest at the lowest loading rate of $500 \mathrm{ml} / \mathrm{min} /$ $\mathrm{m}^{2}$ (or $0.72 \mathrm{~m}^{3} / \mathrm{m}^{2} / \mathrm{d}$ ). In particular, the $\mathrm{TP}, \mathrm{PO}_{4}^{3-}$; $\mathrm{TKN}$ and $\mathrm{NH}_{4}-\mathrm{N}$ removal efficiencies were $95.4 \pm 1.5 ; 54.4 \pm$ $8.5 \% ; 74 \pm 17 \%$ and $68 \pm 21 \%$ for reed grass, respectively, while they were $95.0 \pm 0.7,50.1 \pm 11.5 \%, 68 \pm$ $16 \%$ and $64 \pm 15 \%$, respectively, for vetiver grass. The reference (without flora) was 20-30\% lower in all removal rates. As the loading rates increased, the removal rates decreased accordingly and varied with types of plants. Besides the loading rate, and the type of plants, the plant's maturity might impact the formation of microorganism community in the plant roots, leading to the variation in the nutrient removal. In overall, the constructed wetland systems helped treat the wastewater to meet the national technical regulation on surface water quality, used for agricultural irrigation purposes (QCVN 08-MT: 2015/BTNMT, Column B1).

\section{AUTHOR CONTRIBUTIONS}

Nguyen Minh KY, Nguyen Tri Quang HUNG and Nguyen Cong MANH were resposible for setting up the experiment models and doing the experiments. Bui Quoc LAP supervised the experiment activities, prepared the manuscript and played the role of the corresponding author. Huyen Thi Thanh DANG supported to data handling and analysis as well as manuscript editing. Akinori OZAKI supported to the manuscript arrangement and revision.

\section{ACKNOWLEDGMENTS}

The authors express grateful acknowledgement to the Nong Lam University of Ho Chi Minh for providing funds and test site for this research.

\section{REFERENCES}

Abou-Elela S. I., M. S. Hellal 2012. Municipal wastewater treatment using vertical flow constructed wetlands planted with Canna, Phragmites and Cyprus. Ecological Engineering., 47: 209-213

Aboubacar, S., R. Mohamed, A. Jamal, A. Omar and E. Samira 2018. Exploitation of Phragmites australis (Reeds) in Filter Basins for the Treatment of Wastewater. Journal of Environmental Science and Technology, 11: 56-67

Badejo, A. A., D. O. Omole and Ndambuki 2018. Municipal wastewater management using Vetiveria zizanioides planted in vertical flow constructed wetland. Applied Water Science, 8: 110

Brix, H., A. C. Arias 2005. The use of vertical flow constructed welands for on-site treatment of domestic wastewater: New Danish guidelines. Ecological Engineering., 25: 491-500
Carpenter, S. R., N. F. Caraco, D.L. Correll, R. W. Howarth, A. N Sharpley, V. H. Smith 1998. Nonpoint pollution of surface waters with phosphorus and nitrogen. The Ecological Society of America, 8(3): 559-568

Dallas, S., B. Scheffe, G. Ho 2004. Reedbeds for greywater treatment-case study in Santa Elena-Monteverde, Costa Rica, Central America. Ecological Engineering, 23: 55-61

Danh, L. T., P. Truong, R. Mammucari, T. Tran, N. Foster 2009. Vetiver grass, Vetiveria zizanioides: a choice plant for phytoremediation of heavy metals and organic waster. International Journal of Phytoremediation, 11: 664-691

Datta, R., P. Das, S. Smith, P. Punamiya, D. M. Ramanthan, R. Reddy, D. Sarkar 2013. Phytoremediation potential of vetiver grass (Vetiveria zizanioides L.) for tetracycline. International Journal of Phytoremediation, 15: 343-351

Du, L., Chen, Q., Liu, P., Zhang, X., Wang, H., Zhou, Q., Xu, D., Wu, Z 2017. Phosphorus Removal Performance and Biological Dephosphorization Process in Treating Reclaimed Water by Integrated Vertical-Flow Constructed Wetlands (IVCWs). Bioresource Technology. 243: 204-211

Dudai, N., E. Putievsky, D. Chaimovitch, M. Ben-Hur 2006. Growth management of vetiver (Vetiveria zizanioides) under Mediterranean conditions. Journal of Environmental Management, 81: 63-71

Effendi, H., P. C. Delis, M. Krisanti, S. Hariyadi 2015. The performance of nile tilapia (Oreochromis niloticus) and vetiver grass (Vetiveria zizanioides) concurrently cultivated in aquaponic system. Advanced Environmental Biology, 9(24): 382-388

ElZein, Z., A. Abdou, G. AbdEl 2016. Constructed Wetlands as a Sustainable Wastewater Treatment Method in Communities. Procedia Environmental Sciences, 34: 605-617

Eriksson, E., K. Auffarth, M. Henze and A. Ledin 2002. Characteristics of grey wastewater. Urban Water, 4(1): 85-104

Farid, M., M. Irshad, M. Fawad, Z. Ali, A. E. Eneji, N. Aurangzeb, A. Mohammad, B. Ali 2014. Effect of cyclic phytoremediation with different wetland plants on municipal wastewater. International Journal of Phytoremediation, 16(6): 572-581

Guy, W., O. G. Mark, S. G. Paul, G. Vladislav, H. Sally, L. Antoine, M. Björn, G. M. Brendan, D.T. Scott, C. Helen, D. Mike, E. Arturo, F. Verónica, A. S. G. Manuel, F. Tadeusz, O. L. Jean, N. Marius, P. Jesús, R. Geta, S. Markus, V. Angheluta, B. M. V. Lena, C. Eric 2012. Continental-Scale Effects of Nutrient Pollution on Stream Ecosystem Functioning. Science, 336(6087): 14381440

Havens, KJ, H. Berquist, W. I. Priest 2003. Common reed grass, Phragmites australis, expansion into constructed wetlands: Are we mortgaging our wetland future? Estuaries, 26: 417

He, Q. and K. Mankin 2002. Performance variation of COD and removal of nitrogen removal by vegetated submerged bed wetlands. Journal American Water Resource Association, 38 : 1679-1689

Indrayatie, E. R., W. H. Utomo, E. Handayanto, C. W. N. Anderson 2013. The use of vetiver (Vetiveria zizanioides L.) for then remediation of wastewater discharged from tapioca factories. Journal of Environmental Waste Management, 12(1): 1-16

Jarvie, H. P., B. A. Whitton, C. Neal 1998. Nitrogen and phosphorus in east coast British rivers: Speciation, sources and biological significance. Science of The Total Environment, 210-211: 79-109

Kadlec, R. H.; Knight, R. L., (1996). Treatment wetlands, 1st Edition. CRC Press, Boca Raton, Florida

Kadlec, R. H. and S. D. Wallace 2009. Treatment Wetlands. CRC Press/Lewis Pucblishers, Boca Raton, FL

Kantawanickul, S., S. Kladprasert, H. Brix 2009. Treatment of high-strenght wastewater in tropical vertical flow constructed wetlands planted with Typha angustifolia and Cyperus involucratus. Ecological Engineering, 35: 238-247

Katarzyna, S., H. G. Magdalena 2017. The use of constructed wetlands for the treatment of industrial wastewater. Journal of Water and Land Development, 34: 233-240

Lee, B., M. Scholz 2007 What is the role of Phragmites australis in experimental constructed wetland filters treating urban run- 
off? Ecological Engineering, 29: 87-95

Lu, X., M. Kruatrachue, P. Pokethitiyook, K. Homyok 2004. Removal of Cadmium and Zinc by Water Hyacinth., Eichhornia crassipes. Science Asia, 30: 93-103

Maimon, A., A. Tal, E. Friedler and A. Gross 2010. Safe on-site reuse of greywater for irrigation-a critical review of current guidelines. Environmental Science and Technology, 44: 3213-3220

Manuel, J. 2014. Nutrient pollution: a persistent threat to waterways. Environmental health perspectives, 122(11): A304A309

Mirco, M. and T. Attilio 2013. Evapotranspiration from pilotscale constructed wetlands planted with Phragmites australis in a Mediterranean environment. Journal of Environmental Science and Health, 48(5): 568-580

Muvea, F. M., Ogendi, G. M., Omondi, S. O. 2019. Nutrient removal efficiency by floating macrophytes; Lemna minor and Azolla pinnata in a constructed wetland. Global Journal of Environmental Science and Management, 5(4): 415-430

Prochaska, C. A., A. I. Zouboulis, K. M. Eskridge 2007. Performance of pilot-scale vertical-flow constructed wetlands, as affected by season, substrate, hydraulic load and frequency of application of simulated urban sewage. Ecological Engineering, 31: 57-66

Roongtanakiat, N. and P. Chairoj 2001. Uptake Potential of Some Heavy Metals by Vetiver Grass. Kasersart J. (Nat. Sci.)., $\mathbf{3 5}$ : $46-50$

Seroja, R., H. Effendi, S. Hariyadi 2018. Tofu wastewater treatment using vetiver grass (Vetiveria zizanioides) and zeliac. Applied Water Science, 8: 2

Tran, D. H., Vi, T. M. H., Dang, T. T. H., Narbaitz, R. 2019. Pollutant removal by Canna Generalis in tropical constructed wetlands for domestic wastewater treatment. Global Journal of Environmental Science and Management, 5(3): 331-344

Travis, M. J., A. Wiel-Shafran, N. Weisbrod, E. Adar and A. Gross
2010. Greywater reuse for irrigation: effect on soil properties. Science of The Total Environment, 408: 2501-2508

Truong, P. N., Y. K. Foong, M. Guthrie, Y. T. Hung 2010. Phytoremediation of heavy metal contaminated soils and water using vetiver grass. Environ. Bioengineering, 11: 233-275

Vymazal, J. 2002. The use of subsurface constructed wetlands for wastewater in Czech Republic: 10 years experience. Ecological Engineering, 18: 633-646

Vymazal, J. 2009. The use of constructed wetlands with horizontal sub-surface flow for various types of wastewater. Ecological Engineering, 35: 1-17

Vymazal, J. 2010. Constructed Wetlands for Wastewater Treatment. Water, 2: 530-549

Wang, R., Baldy V., Perissol C., N. Korboulewsky 2012. Influence of plants on microbial activity in a vertical dowflow wetland system treating waste activated sludge with high organic matter concentrations. Journal of Environmental Management, $\mathbf{9 5}$ S158-S164

Xinyu, L., C. Hontao, J. Xueyan, Y. Zhigang, Y. Qingzhen 2017. Impacts of human activities on nutrient transport in the Yellow River: The role of the Water-Sediment Regulation Scheme. Science of The Total Environment, 592: 161-170

Zeshan, A., M. Ashiq, R. Yousaf, M. Q. Umar, NM. Riffat 2018. Treatment efficiency of a hybrid constructed wetland system for municipal wastewater and its suitability for crop irrigation. International Journal of Phytoremediation, 20(11): 11521161

Zhang, D. Q., Jinadasa, K., Gersberg, R. M., Liu, Y., Ng, W. J., Tan, S. K. 2014. Application of constructed wetlands for wastewater treatment in developing countries: A review of recent developments (2000-2013). Journal of Environment Management. 141: 116-131

Zurita, F. D. A. 2009. Treatment of domestic wastwater and production of commercial flower. Ecological Engineering, 35(5): 861-869 